\title{
Acute copper toxicity in juvenile fat snook Centropomus parallelus (Teleostei: Centropomidae) in sea water
}

\author{
Bruno L. Oliveira ${ }^{1}$, Luiz F. Loureiro Fernandes ${ }^{1}$, Adalto Bianchini ${ }^{2}$, Adriana R. Chippari- \\ Gomes $^{3}$, Bruno F. Silva ${ }^{3}$, Geisamanda P. Brandão ${ }^{1}$ and Levy C. Gomes ${ }^{3}$
}

Three experiments were designed to assess the accumulation and acute toxicity of copper $(\mathrm{Cu})$ in juvenile fat snook Centropomus parallelus. The first experiment was performed to determine the $96-\mathrm{h}$ lethal concentration $\left(\mathrm{LC}_{50}\right)$ of $\mathrm{Cu}$. The second experiment was designed to assess the effects of sublethal concentrations of $\mathrm{Cu}(0.47$ and $0.94 \mathrm{mg} / \mathrm{L})$, while the third one allowed us to test the recovery capacity of fish exposed to the sublethal concentrations $\mathrm{Cu}$ and kept in sea water without $\mathrm{Cu}$ addition. The $\mathrm{LC}_{50}$ value for $\mathrm{Cu}$ was found to be $1.88 \mathrm{mg} / \mathrm{L} \mathrm{Cu}$. Fish exposed to the sublethal concentrations of $\mathrm{Cu}$ showed a significant accumulation of $\mathrm{Cu}$ in gills at $96 \mathrm{~h}$ respect to the control ones $(0.43 \mu \mathrm{g} / \mathrm{g} \mathrm{Cu})$. No significant difference was observed in the accumulation of $\mathrm{Cu}$ in gills between fish exposed to $0.47 \mathrm{mg} / \mathrm{L}(1.09 \mu \mathrm{g} / \mathrm{g} \mathrm{Cu})$ and $0.94 \mathrm{mg} / \mathrm{L}(1.26 \mu \mathrm{g} / \mathrm{g} \mathrm{Cu})$. Exposure $(24$ and $96 \mathrm{~h})$ to the sublethal concentrations of $\mathrm{Cu}$ tested induced DNA damage in the erythrocytes. The results show that acute exposure to sublethal concentrations induces $\mathrm{Cu}$ accumulation and DNA damage in fish, these effects being recovered after $240 \mathrm{~h}$ in sea water without $\mathrm{Cu}$ addition.

Três experimentos foram realizados para avaliar o acúmulo e toxicidade aguda do cobre $(\mathrm{Cu})$ em juvenis de robalo-peva Centropomus parallelus. O primeiro experimento foi realizado para determinar a concentração letal $\left(96 \mathrm{~h}-\mathrm{CL}_{50}\right)$ de $\mathrm{Cu}$. O segundo experimento foi realizado para avaliar os efeitos de concentrações subletais de $\mathrm{Cu}(0,47$ e $0,94 \mathrm{mg} / \mathrm{L})$, enquanto o terceiro permitiu testar a capacidade de recuperação dos peixes expostos a concentrações subletais do $\mathrm{Cu}$ e posteriormente mantidos em água do mar sem acréscimo de $\mathrm{Cu}$. $\mathrm{O}$ valor de $\mathrm{LC}_{50}$ encontrado para o $\mathrm{Cu}$ foi de $1,88 \mathrm{mg} / \mathrm{L}$. Os peixes expostos as concentrações subletais de Cu mostraram um acúmulo significativo nas brânquias em relação ao controle em $96 \mathrm{~h}$ de exposição $(0,43 \mu \mathrm{g} / \mathrm{g} \mathrm{Cu})$. Nenhuma diferença significativa foi observada entre os peixes expostos a $0,47 \mathrm{mg} / \mathrm{L}$ de $\mathrm{Cu}(1,09 \mu \mathrm{g} / \mathrm{g})$ e $0,94 \mathrm{mg} / \mathrm{L} \mathrm{de} \mathrm{Cu}(1,26$ $\mu \mathrm{g} / \mathrm{g})$. A exposição (24 e $96 \mathrm{~h}$ ) para as concentrações subletais de Cu induziram danos no DNA. Os resultados mostram que a exposição aguda a concentrações subletais induz o acúmulo de $\mathrm{Cu}$ e danos ao DNA nas brânquias dos peixes, onde estes efeitos são recuperados após $240 \mathrm{~h}$ em água do mar sem adição de $\mathrm{Cu}$.

Key words: Aquatic toxicology, Comet assay, Gills, Lethal toxicity, Micronucleus test.

\section{Introduction}

Aquatic animals are naturally exposed to various metals, and both geochemical processes and human activities govern the chemical form and concentration of these chemical contaminants in water (Sousa et al., 2007). Mining, smelting, and other industrial activities generate soluble or particulate material residues that are further released via the atmospheric or industrial wastes. These residues are destined to end up in most estuaries, seas, and oceans as toxic metals and compounds (Lokhande et al., 2011).

Copper $(\mathrm{Cu})$ is an important metal employed in many industrial processes, being considered as highly toxic to biota, even at low concentrations (Who, 1998). Moreover is an essential trace element that plays a critical role in the biochemistry of aerobic organisms. In man, this metal is

\footnotetext{
${ }^{1}$ Universidade Federal do Espírito Santo - Base Oceanográfica. Rodovia ES-010 km 16, 29199-970 Aracruz, ES, Brazil. brunodlo@yahoo.com.br(BLO); luiz.ufes@gmail.com(LFLF); geisamanda@gmail.com (GPB)

${ }^{2}$ Universidade Federal do Rio Grande - FURG, Instituto de Ciências Biológicas. Avenida Itália km 8, $96203-900$ Rio Grande, RS, Brazil. adaltobianchini@furg.br

${ }^{3}$ Universidade Vila Velha, UVV. Comissário José Dantas de Melo, 21, 29102-770 Vila Velha, ES, Brazil. adriana.chippari@uvv.br(ARCG); bferreiradasilva@gmail.com(BFS); levy.gomes@uvv.br(LCG)
} 
utilized by a diverse but limited number of enzymes to enable electron transfer reactions in key metabolic pathways (Culotta \& Gitlin, 2001).

Several methods have been employed to determine $\mathrm{Cu}$ contamination in aquatic organisms (Lemos, 2005; Moller, 2006; Jorge et al., 2013). Many authors suggest the use of genotoxic analyses, such as the comet assay and micronucleus test (Avishai et al., 2002; Matsumoto et al., 2006). These methods have some advantages, since they can be used for simultaneous evaluation of the degree of DNA lesions in many tissues of the tested individual, thus enabling comparisons among tissue responses under identical treatment conditions. Therefore, these methods can be used together to screen chemical substances and further investigate associations with DNA damage and recovery of sentinel species, such as fish (Ali et al., 2009).

The fat snook, Centropomus parallelus, inhabits shallow coastal and estuarine waters from the Southern Florida to the Brazilian coast (tropical and subtropical waters), and does not undergo long migrations (Rivas, 1962; Martin \& King, 1991). C. parallelus are top predators, relying on fish and shellfish as their most important sources of food (Chaves, 1963). Analysis of the sublethal effects of $\mathrm{Cu}$ on key prey species, such as the fat snook, is of paramount importance to evaluate the negative impacts on the population fitness, as well as to assess a possible metal biomagnification throughout the food chain. Exposure of $C$. parallelus to $\mathrm{Cu}$ has been already tested in fresh water (Oss et al., 2013). However, the degree of $\mathrm{Cu}$ accumulation and its consequent toxicity are highly dependent on the water chemistry. In the present study, experiments were performed using sea water, where $\mathrm{Cu}$ toxicity to aquatic animals is shown to be reduced (Martins \& Bianchini, 2008). Experiments were performed to assess the lethal concentration of $\mathrm{Cu}$ to juveniles of the C. parallelus, as well as the DNA damage induced by $\mathrm{Cu}$ accumulation of fish exposed to sublethal concentrations. Finally, was also observed, the fish ability to recover after acute exposure to sublethal concentrations of $\mathrm{Cu}$.

\section{Material and Methods}

\section{Experimental water and fish}

The sea water used in the experiments was collected at the estuarine area of the Piraqueaçu River (Espírito Santo State, southeastern Brazil). After collection, sea water was filtered using a sequence of Cuno filters $(20,10$, and $5 \mu \mathrm{m})$ and sterilized using an ultraviolet (UV) filter system. Physicochemical parameters (temperature, salinity, $\mathrm{pH}$, and conductivity) of the sea water were determined over the experimental period.

Juveniles (mean value \pm standard error; body mass: $3.5 \pm$ $1.7 \mathrm{~g}$; total body length: $6.8 \pm 1.3 \mathrm{~cm} ; \mathrm{n}=288$ ) of the Centropomus parallelus were bought from a fish farm and acclimated to sea water in two $1000 \mathrm{~L}$ tanks for 25 days. Fish were fed daily with a commercial feed containing $60 \%$ protein (Inve, Belgium).

\section{Acute $\mathrm{Cu}$ toxicity}

After acclimation, fish were randomly transferred to eighteen $30 \mathrm{~L}$ tanks (10 fish per tank). The tanks were equipped with constant aeration, and oxygen levels maintained closed to the saturation. Five concentrations of $\mathrm{Cu}\left(\right.$ as $\left.\mathrm{CuSO}_{4} .5 \mathrm{H}_{2} \mathrm{O}\right)$ were then tested: $0.4,0.8,1.6,3.2$, and $6.0 \mathrm{mg} / \mathrm{L} \mathrm{Cu}$. One control test (no $\mathrm{Cu}$ addition to water) was also run. The tested concentrations were determined in a preliminary test. All tests were performed in triplicate. Fish mortality was determined every $24 \mathrm{~h}$ for $96 \mathrm{~h}$. Death criteria adopted was the lack of movement and no reaction to tactile stimuli. The lethal concentration of $\mathrm{Cu}$ for $50 \%$ of the individuals tested after $96 \mathrm{~h}\left(96-\mathrm{h} \mathrm{LC}_{50}\right)$ was calculated based on the cumulative mortality data using the Trimmed Spearman-Karber method (Hamilton et al., 1977).

\section{Exposure to sublethal $\mathrm{Cu}$ concentrations}

Based on the 96-h $\mathrm{LC}_{50}$ value determined as described above, another experiment was conducted to determine the sublethal effects of $\mathrm{Cu}$ on juvenile fat snook. Combinations of three $\mathrm{Cu}$ concentrations (nominal $=0,0.47$ and $0.94 \mathrm{mg}$ / $\mathrm{L}$; measured $=0.03 \pm 0.01,0.53 \pm 0.07$, and $1.03 \pm 0.14 \mathrm{mg} / \mathrm{L} \mathrm{Cu})$ and two exposure periods (24 and $96 \mathrm{~h}$ ) were tested. $\mathrm{Cu}$ concentrations tested corresponded to around $0,25 \%$ and $50 \%$ of the $96-\mathrm{h} \mathrm{CC}_{50}$ value determined for $\mathrm{Cu}$. Ten fish were tested in each combination of $\mathrm{Cu}$ concentration and exposure period, totalizing 60 experimental units. Fish were individually exposed to $\mathrm{Cu}$ in $2 \mathrm{~L}$ tanks. After exposure, fish were collected, anesthetized (benzocaine; $100 \mathrm{mg} / \mathrm{L}$ ), and had their blood sampled by puncture of the caudal vein using a heparinized syringe. Blood samples were placed in Eppendorf tubes for comet assay and micronucleus test. Gills were then dissected and immediately rinsed in an EDTA $(1 \mathrm{mM})$ solution to remove the loosely bound $\mathrm{Cu}$. Samples were used for measurement of gill $\mathrm{Cu}$ content. Samples of the experimental media were collected at 2, 24 and $96 \mathrm{~h}$ of exposure and acidified $\left(1 \% \mathrm{HNO}_{3}\right.$; Suprapur, Merck) for $\mathrm{Cu}$ concentration measurement.

\section{Fish recovery experiment}

The third experiment was performed with 48 juvenile fat snook exposed to a concentration corresponding to $50 \%$ of the $96 \mathrm{~h} \mathrm{LC}_{50}$ value of $\mathrm{Cu}(0.94 \mathrm{mg} / \mathrm{L} \mathrm{Cu})$ for $96 \mathrm{~h}$. Fish were divided into eight $30 \mathrm{~L}$ plastic tanks (six fish per tank). Four control (no $\mathrm{Cu}$ addition into the sea water) and four $\mathrm{Cu}$ $(0.94 \mathrm{mg} / \mathrm{L} \mathrm{Cu})$ tanks were tested. After exposure, fish from each tank were transferred to a new $30 \mathrm{~L}$ plastic tank containing control sea water (no $\mathrm{Cu}$ addition) to test the fish ability to recover from the pre-exposure to $\mathrm{Cu}$. After 96 and $240 \mathrm{~h}$ of the recovery period, three fish were collected from each tank, anesthetized (benzocaine, $100 \mathrm{mg} / \mathrm{L}$ ) and 
had their blood sampled for comet assay and micronucleus test, as described in the previous item. Gills were then dissected and immediately rinsed in an EDTA $(1 \mathrm{mM})$ solution to remove the loosely bound $\mathrm{Cu}$. Samples were further used for measurement of gill $\mathrm{Cu}$ content. Also, samples of the experimental water media were collected at 0 and $96 \mathrm{~h}$ of the exposure period to $\mathrm{Cu}$, and at 96 and $240 \mathrm{~h}$ of the recovery period. Water samples were acidified $(1 \%$ $\mathrm{HNO}_{3}$; Suprapur, Merck) and further used for $\mathrm{Cu}$ concentration analysis.

\section{Analytical procedures}

Water $\mathrm{Cu}$ concentration and gill $\mathrm{Cu}$ content measurements

$\mathrm{Cu}$ concentration in water samples were determined by atomic absorption spectrophotometry (detection limit $=10$ $\mu \mathrm{g} / \mathrm{L}, \ddot{\mathrm{e}}=324.7 \mathrm{~nm}, \mathrm{GBC}$ Avanta 932, IL, USA) following procedures described by Pinho \& Bianchini (2010) and Monteiro et al. (2013).

Gill samples were weighed, dried at $80^{\circ} \mathrm{C}$, and digested with $10 \% \mathrm{HNO}_{3}$ (Suprapur; Merck) for $24 \mathrm{~h}$. Completely digested samples were diluted using MilliQ water. Tissue $\mathrm{Cu}$ content was determined by atomic absorption spectrophotometry (GBC Avanta 932, IL, USA), following procedures previously described by Carvalho et al. (2013). Results were expressed as $\mu \mathrm{g} / \mathrm{g} \mathrm{Cu}$.

\section{Comet assay}

DNA fragment analysis was evaluated in fish erythrocytes using the alkaline comet assay and silver nitrate staining as described by Tice et al. (2000). Two glass slides for each fish were previously coated with $1.5 \%$ agarose (1.80 g agarose and $120 \mathrm{~mL}$ alkaline phosphate buffer; $\mathrm{pH}$ 7.4). Blood samples were 20 times diluted with a phosphate buffer solution. An aliquot $(10 \mu \mathrm{L})$ of the diluted blood was mixed with $100 \mu \mathrm{L}$ of low melting-point agarose $(0.15 \mathrm{~g}$ agarose in $20 \mathrm{~mL}$ alkaline phosphate buffer, $\mathrm{pH} 7.4$ ) at $40^{\circ} \mathrm{C}$. Slides were covered with coverslips to spread the gel and left stand until its solidification. After removing the coverslips, slides were placed into a lyses solution prepared with $146.1 \mathrm{~g} \mathrm{NaCl}$ (2.5 M), 37.2 g EDTA (100 mM), $1.2 \mathrm{~g}$ Tris $(10 \mathrm{mM}), 1 \mathrm{~L}$ distilled water. The $\mathrm{pH}$ of the solution was adjusted to 13 with $\mathrm{NaOH}$.Triton X-100 (1\%) and DMSO (10\%) were added at the time of use. Slides were left in a refrigerator and protected from light for at least $2 \mathrm{~h}$. After cell lyses, slides were placed in an electrophoretic apparatus and submerged into an electrophoresis buffer solution $(300 \mathrm{mM} \mathrm{NaOH}$ and $1 \mathrm{mM}$ EDTA, $\mathrm{pH}>13$ ) for $20 \mathrm{~min}$. The electrophoretic run was performed at $25 \mathrm{~V}$ and $300 \mathrm{~mA}$ for $15 \mathrm{~min}$. Slides were then neutralized with a Tris buffer solution, washed with distilled water, dried at $37^{\circ} \mathrm{C}$ for $2 \mathrm{~h}$, fixed in fixing solution (15\% trichloroacetic acid, $5 \%$ zinc sulfate heptahydrate, $5 \%$ glycerol, and $1 \mathrm{~L}$ distilled water) for $10 \mathrm{~min}$, washed three times with distilled water, and dried at $37^{\circ} \mathrm{C}$ for $2 \mathrm{~h}$. After drying, slides were hydrated with distilled water for $5 \mathrm{~min}$ and stained with a silver staining solution prepared with 66 $\mathrm{mL}$ of a calcium carbonate solution (12.5 g calcium carbonate dissolved in $250 \mathrm{~mL}$ distilled water) and $34 \mathrm{~mL}$ of a silver nitrate solution ( $50 \mathrm{mg}$ of silver nitrate, $50 \mathrm{mg}$ of ammonium nitrate, $250 \mathrm{mg}$ tungostosilicic acid dissolved in $125 \mu \mathrm{L}$ formaldehyde). Slides were stained at $37^{\circ} \mathrm{C}$ for $15 \mathrm{~min}$.

Cell DNA damage was assessed in 100 cells using an optical microscope (Nikon, Model 50i) and subsequently classified into four damage classes according to the Comet tail length: class 0 - cell without a Comet tail; class 1 - cell showing a Comet tail length shorter than the nucleus diameter; class 2 - cells with a Comet tail length 1 - to 2 -fold larger than the nucleus diameter; class 3 - cell showing a Comet tail length more than 2-fold larger than the nucleus diameter (Grazeffe et al., 2008). The damage index (DI) was calculated based on the sum of the number of damaged cells multiplied by the respective damage class (0-3), according to Heuser et al. (2008).

\section{Micronucleus test}

Blood was dropped onto a glass slide and smeared. The blood smear was left to dry overnight, fixed in a $100 \%$ methanol bath for $30 \mathrm{~min}$, stained with a 5\% Giemsa solution for $40 \mathrm{~min}$, and observed under an optical microscope (Nikon, Model 50i). The frequence of micronucleated cells was determined based on the analysis of 1,000 erythrocytes per slide (Campana et al., 1999; Grisolia, 2002). The cytogenetic analysis was conducted using the optical microscope at 1000 $\mathrm{x}$ magnification. Micronuclei were identified following the criteria proposed by Fenech et al. (2003). For all treatments, two slides per fish were assessed.

\section{Data presentation and statistical analysis}

Data were expressed as mean \pm standard deviation. Data on gill $\mathrm{Cu}$ content and frequence of micronucleated cells for $\mathrm{Cu}$-exposed fish were compared with those for control fish (no $\mathrm{Cu}$ addition into the water) using the Kruskal-Wallis analysis of variance followed by the Dunn's test. Difference in DNA damage indices between $\mathrm{Cu}$-exposed and control fish was determined using analysis of variance followed by the Dunnett's test. In all cases, the significance level adopted was $95 \%(\mathrm{p}<0.05)$.

\section{Results}

\section{Physicochemical parameters of sea water}

Mean values of the physicochemical parameters of the sea water employed in the experiments were: temperature $=$ $24.6 \pm 0.6^{\circ} \mathrm{C}$; salinity $=32.2 \pm 1.1 ; \mathrm{pH}=7.58 \pm 0.38$; and conductivity $=47.46 \pm 0.20 \mathrm{mS} / \mathrm{cm}$.

\section{Acute $\mathrm{Cu}$ toxicity}

Based on total measured $\mathrm{Cu}$ concentration, the $96-\mathrm{h} \mathrm{LC}_{50}$ value $(95 \%$ confidence interval) was $1.88(1.67-2.11) \mathrm{mg} / \mathrm{L} \mathrm{Cu}$. 


\section{Sublethal exposure to $\mathrm{Cu}$}

No fish mortality was observed over the $96 \mathrm{~h}$ period of exposure.

\section{Gill $\mathrm{Cu}$ content}

After an exposure of $96 \mathrm{~h}$, the $\mathrm{Cu}$ content in gill of fish kept under control condition (no $\mathrm{Cu}$ addition into the water) was $0.43 \pm 0.03 \mu \mathrm{g} / \mathrm{g}$ wet tissue. In fish exposed to 0.47 and $0.94 \mathrm{mg} / \mathrm{L} \mathrm{Cu}$, it was $1.09 \pm 0.26$ and $1.26 \pm 0.19 \mu \mathrm{g} / \mathrm{g}$ wet tissue, respectively. There was a significant increase in gill $\mathrm{Cu}$ content of fish from both $\mathrm{Cu}$ exposure treatments relative to the control. However, there was no significant difference in gill $\mathrm{Cu}$ content between fish from the two $\mathrm{Cu}$ treatments.

\section{Comet assay}

After $24 \mathrm{~h}$ of $\mathrm{Cu}$ exposure, the frequency of damaged erythrocytes was significantly lower in control fish than in those exposed to the highest $\mathrm{Cu}$ concentration $(0.94 \mathrm{mg} / \mathrm{L})$ (Table 1). In turn, the DNA damage index was significantly greater on fish exposed to 0.47 and $0.94 \mathrm{mg} / \mathrm{L} \mathrm{Cu}$ than in control fish (Fig. 1A). After $96 \mathrm{~h}$ exposure, there was a significant increase in the frequency of damaged erythrocytes from fish exposed to 0.47 and $0.94 \mathrm{mg} / \mathrm{L} \mathrm{Cu}$ (Table 1). Also, the same difference was observed for the damage index (Fig. 1A).

\section{Micronucleus test}

Micronucleus frequency was significantly higher in erythrocytes of fish exposed to 0.47 and $0.94 \mathrm{mg} / \mathrm{L} \mathrm{Cu}$ than in control fish in both periods (Fig. 1B).

\section{Recovery}

\section{Water $\mathrm{Cu}$ concentration}

$\mathrm{Cu}$ concentration in the water during the $96 \mathrm{~h}$ exposure period was $1.03 \mathrm{mg} / \mathrm{L} \mathrm{Cu}$, a value within the expected limits of the desired concentration $\left(50 \%\right.$ of the $\left.\mathrm{LC}_{50} ; 0.94 \mathrm{mg} / \mathrm{L}\right)$. During the recovery period $(240 \mathrm{~h}), \mathrm{Cu}$ concentration in sea water employed to maintain control and $\mathrm{Cu}$-exposed fish was always $<0.009 \mathrm{mg} / \mathrm{L}$.

Table 1. Frequency (\%) of classes of DNA damage in erythrocytes of the Centropomus paralellus exposed to $\mathrm{Cu}$ $(0.47$ and $0.94 \mathrm{mg} / \mathrm{L})$ for 24 and $96 \mathrm{~h}$. Data are mean \pm standard deviation. *Denotes significant different mean values between control and $\mathrm{Cu}$-exposed fish $(\mathrm{p} \leq 0.05)$.

\begin{tabular}{ccccc}
\hline \multirow{2}{*}{$\begin{array}{c}\text { Copper } \\
\text { concentration } \\
(\mathrm{mg} / \mathrm{L})\end{array}$} & 0 & 1 & 2 & 3 \\
\cline { 2 - 5 } & \multicolumn{5}{c}{ 24 h of exposure } \\
0 & $22.4 \pm 11.9$ & $29.9 \pm 8.2$ & $20.3 \pm 7.8$ & $27.4 \pm 12.6$ \\
0.47 & $5.1 \pm 4.8$ & $12.6 \pm 5.5$ & $24.8 \pm 10.8$ & $57.5 \pm 17.2$ \\
0.94 & $3.2 \pm 3.9^{*}$ & $10.1 \pm 6.1^{*}$ & $31.5 \pm 11.1$ & $55.2 \pm 16.8^{*}$ \\
\multicolumn{5}{c}{96 h of exposure } \\
0 & $13.2 \pm 3.8$ & $19.8 \pm 4.5$ & $24.8 \pm 6.6$ & $42.2 \pm 9.2$ \\
0.47 & $9.1 \pm 7.3^{*}$ & $15.8 \pm 7.8^{*}$ & $24.1 \pm 7.4$ & $51.0 \pm 18.7^{*}$ \\
0.94 & $3.8 \pm 3.5^{*}$ & $9.6 \pm 5.0^{*}$ & $26.4 \pm 9.7$ & $60.2 \pm 16.4^{*}$ \\
\hline
\end{tabular}

\section{Gill Cu content}

During the recovery period, there was no significant difference in gill $\mathrm{Cu}$ content between control and $\mathrm{Cu}$-exposed fish. Also, there was no significant change in gill $\mathrm{Cu}$ content over time (96 and $240 \mathrm{~h}$ ). The $\mathrm{Cu}$ content in the gill of control fish was $3.48 \pm 0.81 \mu \mathrm{g} / \mathrm{g}$ at $96 \mathrm{~h}$ and $3.04 \pm 0.51 \mu \mathrm{g} / \mathrm{g}$ wet tissue at $240 \mathrm{~h}$. In fish recovered in 96 and $240 \mathrm{~h}$, it was 4.03 \pm 1.51 and $3.12 \pm 0.85 \mu \mathrm{g} / \mathrm{g}$ wet tissue, respectively.

\section{Comet assay}

After $96 \mathrm{~h}$ recovery period, $\mathrm{Cu}$-exposed fish showed a significant decrease in the frequency of damaged erythrocytes (Table 2). There was no decrease of the frequency of damaged erythrocytes after $240 \mathrm{~h}$ of recovery in $\mathrm{Cu}$-exposed fish. Also, the damage index was not significantly different between control and $\mathrm{Cu}$-exposed fish after $96 \mathrm{~h}$ and $240 \mathrm{~h}$ of the recovery (Fig. 2A).
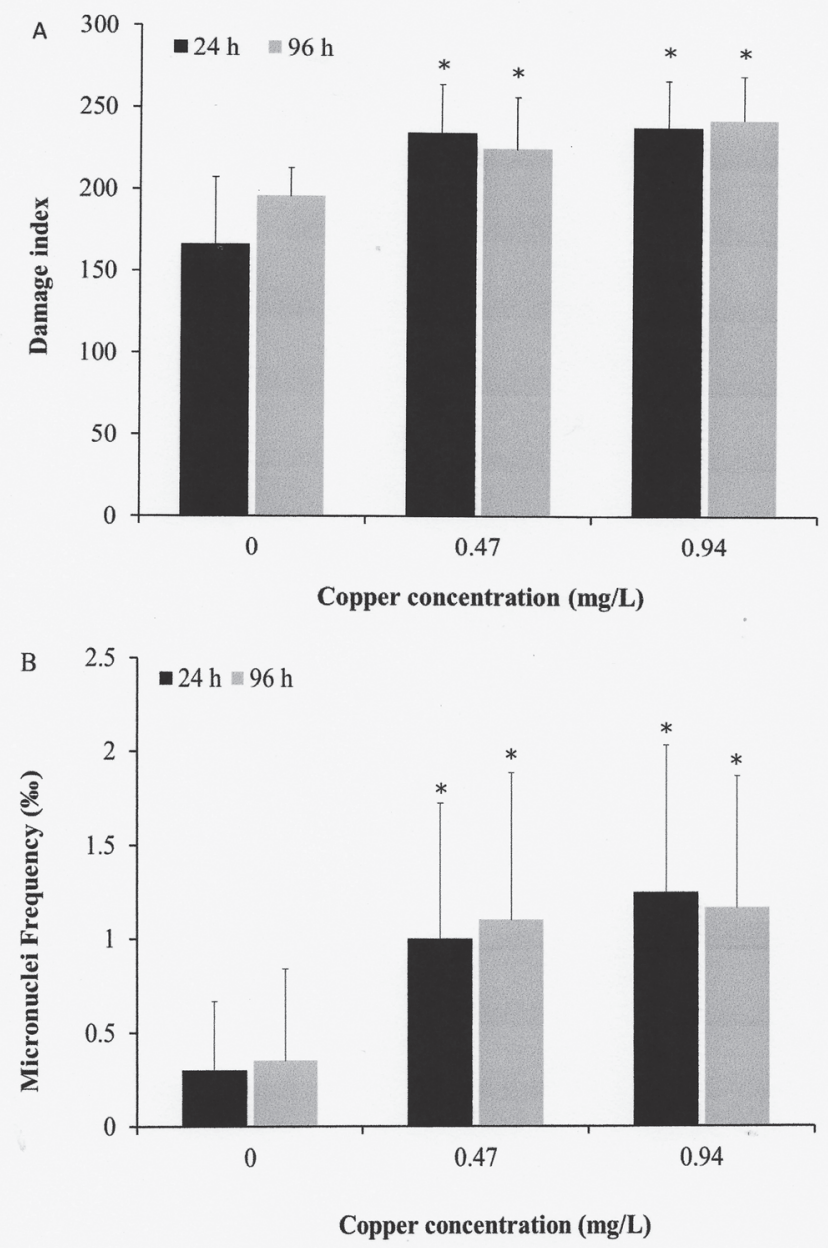

Fig. 1. DNA damage (A) and frequency of micronuclei (B) in erythrocytes of the Centropomus paralellus maintained under control condition or exposed to 0.47 and $0.94 \mathrm{mg} / \mathrm{L}$ of $\mathrm{Cu}$ for 24 and 96 h. *Denotes significant different mean values between control and $\mathrm{Cu}$-exposed fish within the same $\mathrm{Cu}$ concentration and exposure time $(\mathrm{p} \leq 0.05)$. No significant difference was observed between exposure times within the same $\mathrm{Cu}$ concentration $(\mathrm{p}>0.05)$. 


\section{Micronucleus test}

The number of micronuclei was significantly higher in erythrocytes of fish exposed to $0.94 \mathrm{mg} / \mathrm{L} \mathrm{Cu}$ than in those kept under control condition at $96 \mathrm{~h}$ after the start of the recovery period. At the end of the recovery period $(240 \mathrm{~h})$, there was no significant difference between control and $\mathrm{Cu}$ exposed fish (Fig. 2B).

\section{Discussion}

The $\mathrm{LC}_{50}$ for fat snook is two-fold lower than that obtained by El-naga et al. (2005) with another saltwater fish Mugil seheli $(=$ Moolgarda seheli) $(5.36 \mathrm{mg} / \mathrm{L})$. The variation in the $\mathrm{LC}_{50}$ values for the same metal may be due to species type, chemical structure of metal compound, and the conditions of the experiment (water temperature, salinity, oxygen content and $\mathrm{pH}$ ) (El-naga et al., 2005). The $\mathrm{LC}_{50}$ for sea water fish is higher than for some freshwater fish like Prochilodus scrofa (= Prochilodus lineatus) $(0.014 \mathrm{mg} / \mathrm{L}$ $\mathrm{Cu}$ at $\mathrm{pH}$ 8) (Carvalho \& Fernandes, 2006), Tanichthys albonubes $(0.027 \mathrm{mg} / \mathrm{L})$ (Jing et al., 2013). The main reason for this difference is the variation in the $\mathrm{Cu}$ speciation between fresh and sea water, as there is a greater complexation of the metal in sea water consequently lower bioavailability for absorption by fish.

$\mathrm{Cu}$ content data indicated that the waterborne metal is readily accumulated in the gills of the Centropomus parallelus. In fact, fish exposed to 0.47 and $0.94 \mathrm{mg} / \mathrm{L} \mathrm{Cu}$ showed similar gill $\mathrm{Cu}$ content at the end of exposure. This finding indicates that maximum $\mathrm{Cu}$ accumulation occurred, suggesting that gill binding sites were saturated even at the lower concentration of $\mathrm{Cu}$ tested. Similar results were reported by Martins \& Bianchini (2008) for the pompano Trachinotus marginatus exposed to a lower concentration of $\mathrm{Cu}(0.369 \mathrm{mg} / \mathrm{L})$ for $6 \mathrm{~h}$.

Fish gills have shown to be an important biotic ligand for $\mathrm{Cu}$ and have been described as a primary site for

Table 2. Frequency (\%) of classes of DNA damage in erythrocytes of the Centropomus paralellus maintained under control condition (no $\mathrm{Cu}$ addition into the sea water) for the whole experimental period or pre-exposed $(96 \mathrm{~h})$ to $\mathrm{Cu}(0.94$ $\mathrm{mg} / \mathrm{L}$ ), transferred to control sea water and maintained under this condition for recovery during 96 and $240 \mathrm{~h}$. Data are expressed as mean \pm standard deviation. *Denotes significant different mean values between control and fish pre-exposed to $\mathrm{Cu}(\mathrm{p} \leq 0.05)$.

\begin{tabular}{ccccc}
\hline Cu exposition & \multicolumn{4}{c}{ Damage classes } \\
\cline { 2 - 5 } concentration $(\mathrm{mg} / \mathrm{L})$ & 0 & 1 & 2 & 3 \\
\hline \multicolumn{5}{c}{$96 \mathrm{~h}$ of recovery } \\
0.94 & $15.4 \pm 9.0$ & $18.8 \pm 6.8$ & $27.1 \pm 9.0$ & $38.7 \pm 12.3$ \\
0 & $8.1 \pm 6.5^{*}$ & $11.4 \pm 8.6^{*}$ & $25.7 \pm 8.6$ & $54.7 \pm 13.9^{*}$ \\
\hline 0.94 & $240 \mathrm{~h}$ of recovery \\
\hline
\end{tabular}

accumulation of $\mathrm{Cu}$ from the dissolved phase (Romeo et al., 1994; Zia \& McDonald, 1994; Martins \& Bianchini, 2008). According to Santore et al. (2001), Cu toxicity in fish occurs when the accumulation of this metal at the gill tissue exceeds the saturation capacity of binding sites, especially those associated with the $\mathrm{Na}^{+}$and $\mathrm{Ca}^{2+}$ channels. Despite the fact that a saturation of $\mathrm{Cu}$ binding sites at the gills of $C$. parallelus was observed, there was no fish mortality over the experimental period. This finding suggests that other biotic ligand(s) than gills would be also involved in $\mathrm{Cu}$ toxicity in the $C$. parallelus in sea water.

The comet assay allows for differentiation between natural variability and genotoxicity, which is the variation induced in the genetic material by stress associated with contaminants (Lemos, 2005). There are a limited number of studies using the comet assay with marine fish when compared to those performed in freshwater species (Frenzilli et al., 2009). Di Paolo (2006) applied the comet assay in $C$.
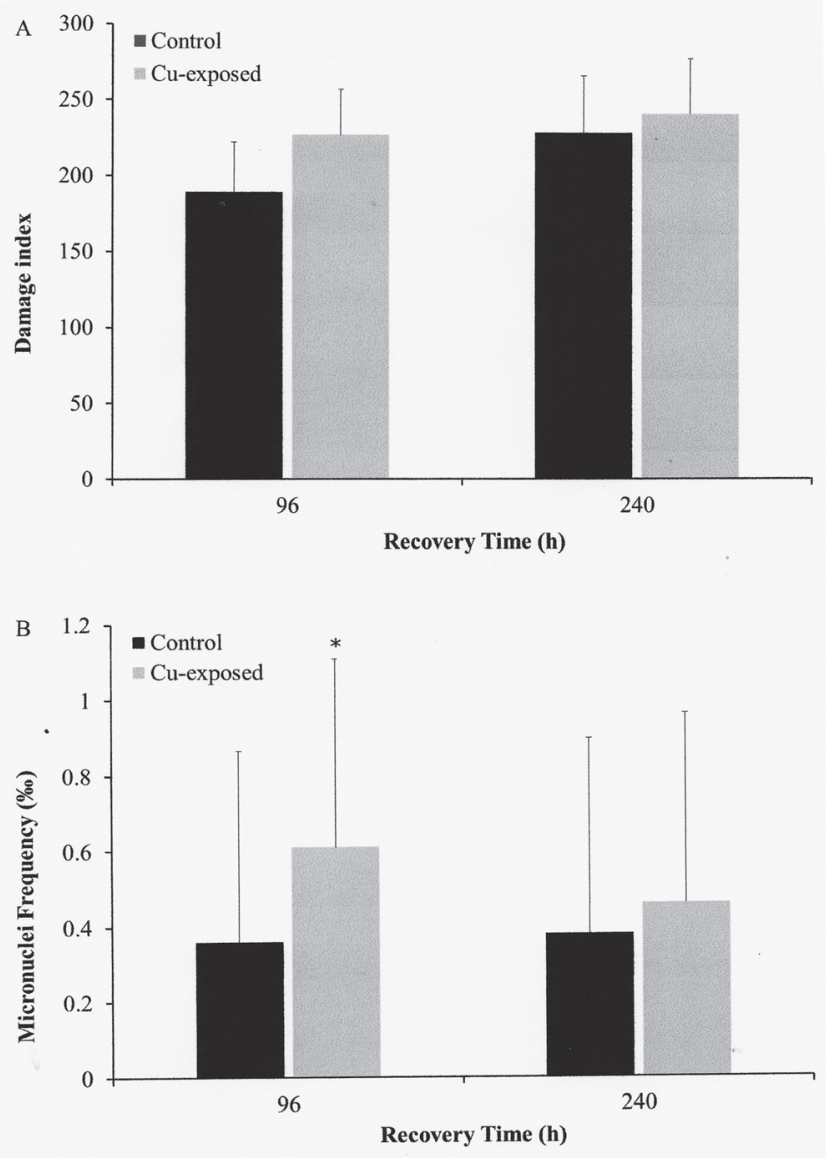

Fig. 2. DNA damage (A) and frequency of micronuclei (B) in erythrocytes in the Centropomus paralellus exposed (96 h) to $\mathrm{Cu}(0.94 \mathrm{mg} / \mathrm{L})$, transferred to control sea water and maintained under this condition for 96 and $240 \mathrm{~h} .{ }^{*}$ Denotes significant different mean values between control and $\mathrm{Cu}-$ exposed fish $(\mathrm{p} \leq 0.05)$. No significant difference was observed between exposure times $(\mathrm{p}>0.05)$. 
parallelus exposed to other xenobiotic (ß-naphthoflavone) and found the method to be very sensitive. For fat snook, DNA damage was significantly higher in $\mathrm{Cu}$-exposed than in control fish, however the comet assay did not detect a significant difference between fish exposed to the two $\mathrm{Cu}$ concentrations tested. The fact that damage was similar in fish exposed to 0.47 and $0.94 \mathrm{mg} / \mathrm{L} \mathrm{Cu}$ even at $24 \mathrm{~h}$ of exposure indicates that $\mathrm{Cu}$ affects DNA as soon it reaches and accumulates in the fish blood.

Micronuclei were observed in most studies of short-term exposure (24- $96 \mathrm{~h}$ ) and are considered sensitive biomarkers of genotoxicity (Cavas et al., 2005). Kirschbaum et al. (2009) compared the micronucleus frequency in erythrocytes of $C$. parallelus from a polluted (São Vicente) and a protected estuary (Cananéia) at São Paulo State (southeastern Brazil). They reported values up to 10 -fold higher in fish from the polluted site respect to those from the protected site, indicating that the micronucleus assay is reliable for monitoring the health of marine and estuarine ecosystems. In this study, micronucleus frequency was found to be 3fold higher in fish exposed to $\mathrm{Cu}(0.47$ and $0.94 \mathrm{mg} / \mathrm{L})$ than in those kept under control conditions. Despite the effect observed in erythrocytes of C. parallelus, $\mathrm{Cu}$ genotoxicity seemed to be lower than that observed in freshwater species. For example, Cavas et al. (2005) subjected Cyprinus carpio to 0.01 and $0.25 \mathrm{mg} / \mathrm{L} \mathrm{Cu}$ and the results showed micronucleus frequency almost 4 -fold higher than that observed in C. parallelus.

According to Grazeffe et al. (2008), increased concentrations of contaminants induce additional damage to the genetic material. However, once the contaminant is removed the level of damage repair is expected to increase. Analysis of the gill $\mathrm{Cu}$ content over the recovery period indicated a depuration of $\mathrm{Cu}$ from the gill tissue of the fat snook. In fact, no significant difference in gill $\mathrm{Cu}$ content was observed between control and $\mathrm{Cu}$-exposed fish after the recovering period. A very similar response was reported by Boock \& Machado-Neto (2000), who reported almost complete depuration of $\mathrm{Cu}$ in fish subjected to a $144 \mathrm{~h}$ period of recovery in "clean" water after being exposed to $\mathrm{Cu}$ oxychloride for $96 \mathrm{~h}$. At this point, it is interesting to note that lesions detected through the comet assay, are amenable to correction (Tice et al., 2000), and therefore considered as being pre-mutagenic (Kammann et al., 2001). In the present study, the higher damage index detected through the comet assay after $96 \mathrm{~h}$ of exposure to $\mathrm{Cu}$ was not seen anymore after the $240 \mathrm{~h}$ depuration period. This finding indicates a repair of injuries to the genetic material caused by the acute exposure to $\mathrm{Cu}$.

Although micronuclei are often reported as genotoxicity biomarkers in aquatic animals, studies on fish exposed to pollutants have indicated that the micronucleus frequency in erythrocytes tends to decrease over time (Campana et al., 1999; Cavas \& Ergene-Gozukara, 2005). In the present study, a reduced number of erythrocytes with micronuclei were also observed in fish exposed to $\mathrm{Cu}$ and subjected to the recovery period respect to those kept only under control conditions. However, this response was only seen after $240 \mathrm{~h}$ of the beginning of the recovery period, but not after $96 \mathrm{~h}$. Oss et al. (2013) showed that micronucleus frequency in erythrocytes did not decrease in C. parallelus 30 days after subchronic exposure to $25 \mu \mathrm{g} / \mathrm{L} \mathrm{Cu}$ in fresh water. The low micronuclei frequency observed in C. parallelus in sea water could be explained considering a higher rate of erythrocyte renewal in $\mathrm{Cu}$-exposed fish than in control ones. During blood cell kinetics, erythrocytes are continuously renewed and the damaged erythrocytes tend to be eliminated from the body more quickly than the undamaged cells (Flora et al., 1993).

As pointed by Hagger et al. (2006), C. parallelus can be considered a relevant species in monitoring programs using biomarkers. Findings of this study are in complete agreement with this idea. In fact, the combination of the two assays used showed to be adequate and useful in evaluating $\mathrm{Cu}$ genotoxicity in C.parallelus induced by sublethal exposure to $\mathrm{Cu}$ in sea water.

\section{Acknowledgments}

We would like to thank to Dr. Dominik Lenz for the critical review of the paper. This work was supported by CNPq grant \#559090/2009-9 and \#562821/2010-4, and FAPES grant $\# 53235282 / 2011$. A. Bianchini and L.C. Gomes are a researchers fellowship recipient from $\mathrm{CNPq} / \mathrm{Brazil}$, and $\mathrm{A}$. Bianchini is supported by the International Research Chair Program from the International Development Research Center (DRC; Ottawa, ON, Canada).

\section{Literature Cited}

Ali, D., N. S. Nagpure, S. Kumar, B. Kushwaha \& W. S. Lakra. 2009. Assessment of genotoxic and mutagenic effects of chlorpyrifos in freshwater fish Channa punctatus (Bloch) using micronucleus assay and alkaline single-cell gel electrophoresis. Food and Chemical Toxicology, 47: 650-656.

Avishai, N., C. Rabinowitz, E. Moiseeva \& B. Rinkevich. 2002. Genotoxicity of Kishon River, Israel: the application of an in vitro cellular assay. Mutation Research, 518: 21-37.

Boock, M. V. \& J. G. Machado Neto. 2000. Estudos toxicológicos do oxicloreto de cobre para tilápia vermelha (Oreochromis sp.). Arquivos do Instituto de Biologia 67: 215-221.

Campana, M. A., A. M. Panzeri, V. J. Moreno \& F. Dulout. 1999. Genotoxic evaluation of the pirethroid lambda-cyhalothrin using the micronucleus test in erytrocytes of the fish Cheirodon interruptus interruptus. Mutation Research, 438: 155-161.

Carvalho, P. C., L. Bugoni, R. A. R. McGill \& A. Bianchini. 2013. Metal and selenium concentrations in blood and feathers of petrels of the genus Procelaria. Environmental Toxicology and Chemistry, 32. 1641-1648.

Carvalho, C. S. \& M. N. Fernandes. 2013. Effect of temperature on copper toxicity and hematological responses in the neotropical fish Prochilodus scrofa at low and high pH. Aquaculture, 251: 109-117. 
Cavas, T. \& S. Ergene-Gozukara. 2005. Micronucleus test in fish cells: a bioassay for in situ monitoring of genotoxic pollution in the marine environment. Environmental and Molecular Mutagenesis, 46: 64-70.

Cavas, T., N. N. Garanko \& V. V. Arkhipchuk. 2005. Induction of micronuclei and binuclei in blood, gill and liver cells of fishes subchronically exposed to cadmium chloride and copper sulphate. Food and Chemical Toxicology, 43: 569-574.

Chaves, H. 1963. Contribucion al conocimiento de la biología de los robalos, chucumite y constantino (Centropomus spp.) del estado de Veracruz. Contribución de la Estación de Biología Marina del Instituto Tecnológico de Veracruz. México: Ciência, 22: 141161.

Culotta, V. C. \& J. D. Gitlin. Disorders of copper transport. 2001. Pp. 3105-3126. In: Scriver, C. R., A. L. Beaudet, W. S. Sly \& D. Valle (Eds.). The Metabolic and Molecular Bases of Inherited Disease. vol 2. New York, McGraw-Hill.

Di-Paolo, C. 2006. Aplicação do ensaio do cometa a estudo de danos ao DNA de robalos, Centropomus parallelus (Poey, 1860), expostos à ß-naftoflavona. Unpublished MS.c. Dissertation, Universidade de São Paulo, São Paulo.

El-naga, E. H. A, K. M. El-moselhy \& M. A. Hamed. 2005. Toxicity of cadmium and copper and their effect on some biochemical parameters of marine fish Mugil seheli. Egyptian Journal of Aquatic Research, 31: 60-71.

Fenech, M., W. P. Cheng, M. Kirsch-Volders, N. Holland, S. Bonassi \& E. Zeiger. 2003. HUMN project: detailed description of the scoring criteria for the cytokinesis-block micronucleus assay using isolated human lymphocyte cultures. Mutation Research, 534: 65-75.

Flora, S., L. Viganó, F. D. Agostini, A. Camoirano, M. Bagnasco, C. Bennicelli, F. Melodia \& A. Arillo. 1993. Multiple genotoxicity biomarkers in fish exposed in situ to polluted river water. Mutation Research, 319: 167-177.

Frenzilli, G., M. Nigro \& B. P. Lyons. 2009. The Comet assay for the evaluation of genotoxic impact in aquatic environments. Mutation Research, 681: 80-92.

Grazeffe, V. S., L. F. Tallarico, A. S. Pinheiro, T. Kawano, M. F. Suzuki, K. Okazaki, C. A. B. Pereira \& E. Nakano. 2008. Establishment of the comet assay in the freshwater snail Biomphalaria glabrata (Say, 1818). Mutation Research, 654: 58-63.

Grisolia, C. K. 2002. A comparison between mouse and fish micronucleus test using cyclophosphamide, mitomycin $\mathrm{C}$ and various pesticides. Mutation Research, 518: 145-150.

Hagger, J. A., M. B. Jones, D. R. Leonard, R. Owen \& T. S. Galloway. 2006. Biomarkers and integrated environmental risk assessment: Are there more questions than answers? Integrated Environmental Assessment and Management, 2: 312-129.

Hamilton, M. A., R. C. Russo \& R. V. Thurston. 1977. Trimmed Spearman-Karber method for estimating median lethal concentrations in toxicity biossays. Environmental Science and Technology, 11: 714-719.

Heuser, V. D., V. M. Andrade, A. Peres, A., L. M. G. Braga \& J. A. B. Chies. 2008. Influence of age and sex on the spontaneous DNA damage detected by micronucleus test and comet assay in mice peripheral blood cells. Cellular Biology, 32: 1223-1229.

Kammann, U., M. Bunke, H. Steinhart \& N. Theobald. 2001. A permanent fish cell line (EPC) for genotoxicity testing of marine sediments with the comet assay. Mutation Research, 498: 61-77.

Jing J., H. Liu, H. Chen, S. Hu, K. Xiao \& X. Ma. 2013. Acute effect of copper and cadmium exposure on the expression of heat shock protein 70 in the Cyprinidae fish Tanichthys albonubes. Chemosphere, 91: 1113-1122.

Jorge, M. B., V. L. Loro, A. Bianchini, C. M. Wood \& P. L. Gillis. 2013. Mortality, bioaccumulation and physiological responses in juvenile freshwater mussels (Lampsilis siliquoidea) chronically exposed to copper. Aquatic Toxicology, 126: 137147.

Kirschbaum, A. A., R. Seriani, C. D. S. Pereira, A. Assunção, D. M. Abessa, M. M. Rotundo \& M. J. T. Ranzani-Paiva. 2009. Cytogenotoxicity biomarkers in fat snook Centropomus parallelus from Cananéia and São Vicente estuaries, SP, Brazil. Genetics and Molecular Biology, 32: 151-154.

Lemos, N. G. 2005. Evaluation of environmental waters using the comet assay in Tilapia rendalli. Environmental Toxicology and Pharmacology, 19: 197-201.

Lokhande, R. S., P. U. Singare \& D. S. Pimple. 2011. Pollution in water of Kasardi River flowing along Taloja industrial area of Mumbai, India. World Environment, 1: 6-13.

Martin, J. H. \& T. T. King. 1991. Occurrence of fat snook (Centropomus parallelus) in Texas: evidence for a range extension. Marine Science, 32: 123-126.

Martins, S. E. \& A. Bianchini. 2008. Copper accumulation and toxicity in the Plata pompano Trachinotus marginatus Cuvier 1832 (Teleostei, Carangidae). Pan-American Journal of Aquatic Sciences, 3: 384-390.

Matsumoto, S. T., M. S. Mantovani, M. I. A. Malaguttii, A. L. Dias, I. C. Fonseca \& M. A. Marin-Morales. 2006. Genotoxicity and mutagenicity of water contaminated with tannery effluents, as evaluated by the micronucleus test and comet assay using the fish Oreochromis niloticus and chromosome aberrations in onion root-tips. Genetics and Molecular Biology, 29: 148-158.

Moller, P. 2006. The alkaline comet assay: Towards validation in biomonitoring of DNA damaging exposures. Basic Pharmacology and Toxicology, 98: 336-345.

Monteiro, S. C. R., G. L. L. Pinho, K. Hoffmann, I. F. Barcarolli \& A. Bianchini. 2013. Acute waterborne copper toxicity to the euryhaline copepod Acartia tonsa: Influence of natural freshwater and marine dissolved organic matter. Environmental Toxicology and Chemistry, 32: 1412-1419.

Oss, R. N., V. D. Baroni, R. M. Duarte, A. L. Val, V. M. Val \& L. C. Gomes. 2013. Recovery of fat snook, Centropomus parallelus (Teleostei: Perciformes) after subchronic exposure to copper. Comparative Biochemistry and Physiology, Part C, 157: 306309.

Pinho, G. L. L. \& A. Bianchini. 2010. Acute copper toxicity in the euryhaline copepod Acartia tonsa: Implications for the development of an estuarine and marine biotic ligand model. Environmental Toxicology and Chemistry, 29: 1834-1840.

Rivas, L. R. 1962. The Florida fishes of the genus Centropomus, commonly known as snook. Quarterly Journal of the Florida Academy of Science, 25: 53-64.

Romeo, M., A. Mathieu, M. Gnassia-Barelli, A. Romana \& M. Lafaurie. 1994. Heavy metal content and biotransformation enzymes in two fish species from the NW Mediterranean. Marine Ecology Progress Series, 107: 15-22.

Santore, R. C., H. E. Allen, D. M. Di Toro, J. S. Meyer \& P. R. Paquin. 2001. Biotic ligant model of the acute toxicity of metals. Application to acute copper toxicity in freshwater fish and Daphnia. Environmental Toxicology and Chemistry, 20: 23972402. 
Sousa, E., D. M. S. Abessa, B. R. F. Rachid, M. R. Gasparro \& L. P. Zaroni. 2007. Ecotoxicological assessment of sediments from the port Santos and the disposal sites of dredged material. Brazilian Journal of Oceanography, 55: 75-81.

Tice, R. R., E. Agurell, D. Anderson, B. Burlinson, A. Hartmann, H. Kobayashi, Y. Miyamae, E. Rojas, J. C. Ryu \& Y. F. Sasaki. 2000. Single cell gel/comet assay: guidelines for in vitro and In vivo genetic toxicology testing. Environmental and Molecular Mutagenesis, 35: 206-22.

Who. 1998. World Health Organization. Copper. Geneva: Environmental Health Criteria 200.

Zia, S. \& D. G. McDonald. 1994. Role of the gills and gill chloride cells in metal uptake in the freshwater adapted rainbow trout Oncorhynchus mykiss. Canadian Journal of Fishery and Aquatic Science, 51:2482-2492.

Submitted March 25, 2014

Accepted may 7, 2014 by Bernardo Baldisserotto Published December 27, 2014 